\title{
Perbandingan Jumlah Limfosit Total pada Anak Gizi Buruk dengan Infeksi dan Tanpa Infeksi HIV
}

\author{
Nur Aisiyah Widjaja, Dina Angelika, Siti Nurul Hidayati, Roedi Irawan \\ Departemen Ilmu Kesehatan Anak Fakultas Kedokteran Universitas Airlangga/RSU Dr. Soetomo, \\ Surabaya
}

Latar belakang. Anak gizi buruk dengan dan tanpa infeksi HIV mempunyai tampilan klinis yang hampir sama. Jumlah limfosit total (TLC) dapat digunakan sebagai parameter respon imun selular pada anak gizi buruk dan sebagai penilaian penurunan respon imun selular pada HIV yang dapat dipakai sebagai skrining awal.

Tujuan. Membandingkan jumlah limfosit total pada anak gizi buruk dengan dan tanpa infeksi HIV.

Metode. Penelitian analitik deskriptif retrospektif dari data sekunder status pasien gizi buruk umur 0-60 bulan yang dirawat di bangsal anak RSUD Dr Soetomo, Surabaya sejak tahun 2004-2009. Data yang diambil adalah data umur, jenis kelamin, dan status infeksi HIV. Diagnosis HIV berdasarkan pemeriksaan serologi tiga metode dan PCR. Semua pasien gizi buruk dengan dan tanpa HIV dihitung jumlah limfosit totalnya. Analisis data menggunakan chi-square dan t-test.

Hasil. Didapatkan 58 anak dengan gizi buruk dan 14 anak disertai dengan infeksi HIV. Nilai rerata TLC pada anak gizi buruk dengan infeksi HIV 2743 (1008-4479), sedangkan tanpa infeksi HIV 6260 (47557766). Kelompok anak gizi buruk dengan infeksi HIV mempunyai TLC lebih rendah dibandingkan tanpa HIV (2743 vs 6260) yang bermakna secara statistik dengan mean difference $-3517(-5740$ sampai -1295 ), $\mathrm{p}=0,003$. Perbedaan bermakna terutama pada kelompok umur 12-23 bulan (2279 vs 7403) dengan mean difference -5124 (-9074 sampai -1168$), \mathrm{p}=0.015$.

Kesimpulan. Anak gizi buruk dengan infeksi HIV mempunyai jumlah limfosit total yang lebih rendah dibandingkan gizi buruk tanpa infeksi HIV terutama pada kelompok umur 12-23 bulan.

Sari Pediatri 2013;15(2):99-104.

Kata kunci: HIV, anak gizi buruk, jumlah limfosit total

Alamat korespondensi:

Dr. Nur Aisiyah Widjaja, Sp.A, Staf Divisi Nutrisi dan Penyakit Metabolik Departemen Ilmu Kesehatan Anak FK Unair/RSU Dr. Soetomo Surabaya. Jl. Prof. Dr. Moestopo 6-8 Surabaya,Telp (031) 5501682. E-mail: nurilo8@yahoo.com

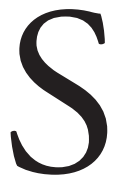

ebagian besar anak dengan infeksi HIV mengalami gizi buruk memiliki tampilan klinis yang hampir sama dengan anak gizi buruk tanpa infeksi HIV. ${ }^{1}$ Di Jawa Timur, terdapat 5260 kasus HIV tercatat sampai dengan September 2009 dengan 147 kasus usia $<14$ tahun. ${ }^{2}$ 
Seiring dengan peningkatan angka kejadian HIV, terutama di Jawa Timur, anak dengan tampilan klinis gizi buruk sering dikaitkan dengan infeksi tersebut. ${ }^{1}$ Pada infeksi HIV, didapat penurunan sistem imunitas selular yang ditandai dengan penurunan jumlah sel limfosit T, khususnya sel T CD4. Seperti halnya infeksi HIV, keadaan gizi buruk juga terdapat penurunan sel T limfosit. ${ }^{3,4}$

Jumlah total limfosit merupakan parameter yang dapat digunakan untuk menilai respons imun selular pada gizi buruk. ${ }^{1}$ Penelitian oleh Gunarsa $\mathrm{dkk}^{5}$ didapatkan hubungan antara jumlah limfosit total $<1200 \mathrm{sel} / \mathrm{mm}^{3}$ dengan status nutrisi pada dewasa. World Health Organization (WHO) menyebutkan bahwa idealnya penilaian penurunan respon imun selular pada infeksi HIV adalah dengan pemeriksaan CD4, tetapi apabila terdapat keterbatasan biaya dan sarana yang tidak memungkinkan untuk pemeriksaan CD4 dapat menggunakan pemeriksaan jumlah total limfosit (total lymphocyte count (TLC). ${ }^{3}$ Beberapa penelitian telah dilakukan untuk menilai kompatibilitas TLC dibandingkan dengan pemeriksaan CD4 dalam menilai respon imun selular pada kasus HIV. Dalam penelitian lain oleh obirikorang dkk, ${ }^{3}$ disebutkan bahwa jumlah limfosit total dapat digunakan sebagai pengukuran dan monitoring terapi terhadap peningkatan respon imun selular apabila tidak bisa melakukan pemeriksaan CD4.

Sampai saat ini belum terdapat penelitian pada anak yang membandingkan jumlah limfosit total pada anak gizi buruk dengan dan tanpa infeksi HIV. Penelitian ini bertujuan untuk menilai jumlah limfosit total pada anak gizi buruk dengan dan tanpa HIV yang dapat dipakai sebagai skrining awal untuk mengetahui kemungkinan infeksi HIV pada anak dengan tampilan klinis gizi buruk.

\section{Metode}

Data sekunder berasal dari status rawat inap di ruang perawatan anak RS Dr. Soetomo, Surabaya sejak tahun 2004 sampai 2009. Kriteria inklusi adalah semua anak umur 0-60 bulan yang sudah didiagnosis gizi buruk dengan penyakit infeksi dan dirawat. Dari semua pasien gizi buruk tersebut dibedakan menjadi dua kelompok, yaitu kelompok pasien dengan infeksi HIV dan kelompok pasien tanpa infeksi HIV. Karakteristik TLC dibandingkan di antara kedua kelompok tersebut.
Infeksi HIV ditegakkan dengan pemeriksaan antibodi HIV 3 metode dan dikonfirmasi dengan pemeriksaan PCR HIV. Kriteria eksklusi adalah pasien yang sudah mendapat obat ARV (antiretroviral).

Pengambilan data dilakukan melalui lembar pengumpulan data (LPD) secara retrospektif dari rekam medis. Variabel yang dianalisis meliputi umur, jenis kelamin, pemeriksaan antropometri, dan nilai jumlah limfosit total. Penilaian status gizi pada menggunakan $\mathrm{Z}$ score $\mathrm{WHO} 2007$, terdiri dari berat badan menurut umur, tinggi badan menurut umur, dan berat badan menurut tinggi badan. Apabila berat badan menurut tinggi badan mempunyai $\mathrm{Z}$ score $<-3$ SD disebut gizi buruk. Pemeriksaan jumlah limfosit total dilakukan secara komputerisasi berdasarkan laboratorium Patologi Klinik RS. Dr. Soetomo dan dilakukan sebelum pasien mendapat obat ARV. Penghitungan nilai jumlah limfosit total adalah persen limfosit dikalikan jumlah limfosit total. Analisis statistik yang digunakan adalah uji t untuk data kuantitatif dan uji chi-square untuk data kualitatif dengan confidence interval (CI) 95\%. Disebut signifikan apabila $\mathrm{p}<0,05$.

\section{Hasil}

Didapatkan 58 pasien gizi buruk yang terdiri dari 14 pasien gizi buruk dengan infeksi HIV dan 44 pasien gizi buruk tanpa infeksi HIV. Tabel 1 menunjukkan distribusi usia dan jenis kelamin pada pasien gizi buruk, baik pada kelompok HIV maupun bukan HIV. Dari 58 anak gizi buruk, didapatkan 34 laki-laki dan 24 perempuan dengan sex ratio 1.4:1, sedangkan dari 14 pasien HIV yang menderita gizi buruk, 10 laki-laki dan 4 perempuan dengan sex ratio 2.5:1. Kelompok usia terbanyak adalah kelompok usia 0-11 bulan, diikuti kelompok usia 12-23 bulan dan 24-47 bulan. Analisis uji chi-square menunjukkan bahwa tidak terdapat perbedaan bermakna antara jumlah masing-masing kelompok usia, baik pada pasien HIV maupun bukan HIV $\left(\mathrm{X}^{2}=9.093, \mathrm{df}=4\right.$, $\mathrm{p}=0,105)$. Analisis uji chi-square juga menunjukkan tidak terdapat perbedaan bermakna antara kelompok jenis kelamin baik pada pasien HIV $\left(\mathrm{X}^{2}=7.467, \mathrm{df}=4\right.$, $\mathrm{p}=0,113)$, maupun bukan HIV $\left(\mathrm{X}^{2}=1.626, \mathrm{df}=4\right.$, $\mathrm{p}=0,898)$.

Tabel 2 menunjukkan perbandingan nilai jumlah limfosit total (TLC) pada kelompok HIV dan bukan 
Tabel 1. Distribusi umur sampel penelitian

\begin{tabular}{lccccc}
\hline \multirow{2}{*}{$\begin{array}{l}\text { Kelompok umur } \\
\text { (bulan) }\end{array}$} & \multicolumn{2}{c}{ HIV-positif $(\mathrm{n}=14)$} & \multicolumn{2}{c}{ HIV-negatif $(\mathrm{n}=44)$} & \multirow{2}{*}{ Total } \\
\cline { 2 - 5 } $0-11$ & Laki laki & Perempuan & Laki laki & Perempuan & \\
\hline $12-23$ & 4 & 0 & 12 & 8 & 24 \\
$24-47$ & 2 & 4 & 5 & 7 & 18 \\
$48-59$ & 2 & 0 & 6 & 4 & 12 \\
\hline
\end{tabular}

${ }^{a} X^{2}=9.093, d f=4, p=0,105 ;{ }^{b} X^{2}=7.467, d f=4, p=0,113 ;{ }^{c} X^{2}=1.626, d f=4, p=0,898$

Tabel 2. Rerata jumlah limfosit total berdasarkan kelompok umur

\begin{tabular}{lcccc}
\hline \multirow{2}{*}{ Kelompok umur (bulan) } & $\begin{array}{c}\text { HIV-positif } \\
\text { TLC (rerata) }\end{array}$ & $\begin{array}{c}\text { HIV-negatif } \\
\text { TLC (rerata) }\end{array}$ & $\begin{array}{c}\text { Mean difference } \\
(95 \% \mathrm{CI})\end{array}$ & $\mathrm{p}$ \\
\hline $0-11$ & 4384 & 7168 & $-2784(-8628 \mathrm{sd} 3958)$ & 0,334 \\
$12-23$ & 2279 & 7403 & $-5124(-9074 \mathrm{sd}-1168)$ & $0,015^{*}$ \\
$24-47$ & 2509 & 3841 & $-1332(-3839 \mathrm{sd} 1175)$ & 0,453 \\
$48-59$ & 1091 & 2431 & $-1340(-4553 \mathrm{sd} 1673)$ & 0,146 \\
Total & 2743 & 6260 & $-3517(-5740 \mathrm{sd} 1295)$ & $0,003^{*}$ \\
\hline
\end{tabular}

${ }^{*} \mathrm{p}<0.05$ by $\mathrm{t}$-test $($ significant $)$

Tabel 3. Sensitivitas dan spesifisitas (TLC) pada kelompok usia 12-23 bulan

\begin{tabular}{lccccccc}
\hline $\begin{array}{l}\text { Kelompok umur } \\
\text { (bulan) }\end{array}$ & $\begin{array}{c}\text { Cut off } \\
\text { TLC }\end{array}$ & $\begin{array}{c}\text { Sensitivitas } \\
(\%)\end{array}$ & $\begin{array}{c}\text { Spesifisitas } \\
(\%)\end{array}$ & Prevalensi & PPV & NPV & +LR \\
\hline $12-23$ & 2455 & 83 & 75 & 33 & 63 & 90 & 3,3 \\
$12-23^{*}$ & 3000 & 86 & 55 & 33 & 50 & 88 & 2,0 \\
$0-59$ & 2455 & 79 & 73 & 24 & 48 & 91 & 2,9 \\
\hline
\end{tabular}

PPV, positive predictive value; NPV, negative predictive value; $+L R$, positive likelihood ratio; ${ }^{*} W H O$ criteria for HIV positive

HIV berdasarkan kelompok umurnya. Terdapat perbedaan bermakna pada total pasien $(\mathrm{p}=0,003)$, dan kelompok umur 12-23 bulan ( $\mathrm{p}=0,015)$. Hal tersebut menunjukkan bahwa nilai TLC lebih rendah signifikan pada gizi buruk dengan infeksi HIV dibandingkan tanpa infeksi HIV, terutama pada kelompok usia 1223 bulan.

Distribusi TLC tertera pada Gambar 1. Tampak bahwa nilai TLC makin menurun sejalan dengan bertambahnya usia. Selain itu, didapatkan pula bahwa nilai TLC pada laki-laki lebih rendah daripada perempuan, tetapi tidak terdapat perbedaan secara statistik.

Nilai jumlah total limfosit dengan garis yang menurun berdasarkan umur. Tidak terdapat perbedaan



Gambar 1. Distribusi TLC (median) berdasarkan umur dan jenis kelamin 




Gambar 2. Kurva ROC jumlah limfosit total untuk cutt off kelompok usia 12-23 bulan

yang bermakna antara jumlah limfosit total berdasarkan jenis kelamin $(\mathrm{p}=0,705)$.

\section{Pembahasan}

Telah banyak diketahui bahwa terdapat hubungan antara infeksi, gizi, dan imunitas seperti lingkaran yang saling berhubungan timbal balik. Adanya infeksi yang berat pada anak gizi buruk menimbulkan kegagalan respon imun selular, terjadi deplesi limfosit terutama sel CD4.

Peningkatan angka kejadian anak gizi buruk yang disertai infeksi HIV, dan adanya gambaran klinis dan laboratoris yang hampir sama sehingga sulit untuk membedakan sebelum dilakukan pemeriksaan serologi untuk membuktikan infeksi HIV. Penting untuk mengetahui kapan seorang anak dengan gizi buruk dicurigai menderita HIV, terutama pada pelayanan kesehatan dasar yang terbatas sehingga tidak terjadi overdiagnosis dan pemeriksaan serologi HIV yang tidak perlu. Pemeriksaan CD4 merupakan parameter yang digunakan untuk menilai kegagalan respons imun selular. Pada pasien HIV, pemeriksaan tersebut digunakan untuk monitoring keberhasilan terapi ARV dan progresifitas dari penyakitnya. Namun, tidak semua sarana kesehatan terutama sarana kesehatan di daerah bisa melakukan pemeriksaan ini. Biaya pemeriksaan CD4 yang mahal menyebabkan pemeriksaan ini jarang digunakan. Sebagai alternatif lain untuk mengetahui respons imun selular dapat digunakan perhitungan jumlah limfosit total. Rekomendasi WHO bahwa apabila terdapat keterbatasan biaya dan sarana yang tidak memungkinkan untuk pemeriksaan CD4 dapat menggunakan pemeriksaan jumlah total limfosit (total lymphocyte count (TLC). Pemeriksaan tersebut bisa dilaksanakan di daerah atau sarana kesehatan terbatas dengan biaya yang jauh lebih murah. Beberapa penelitian yang dilakukan pada dewasa dan anak dinyatakan bahwa jumlah limfosit total (TLC) dapat digunakan untuk menilai respons imun selular.

Kami mencoba mencari nilai cutt off dari jumlah limfosit total yang bisa dipakai sebagai standar untuk menilai derajat respon imun selular pada pasien gizi buruk dengan dan tanpa HIV. Anak dengan kondisi gizi buruk berhubungan dengan limfosit yang rendah secara berkelanjutan dan semakin rendah apabila gizi buruk tersebut disertai dengan infeksi HIV.

Dari Tabel 2 didapatkan bahwa rerata jumlah limfosit total pada pasien gizi buruk dengan HIV lebih rendah dibandingkan gizi buruk tanpa HIV. Perbedaan yang bermakna terhadap jumlah limfosit total (TLC) tampak pada umur 12-23 bulan, didapatkan nilai yang lebih rendah pada pasien gizi buruk dengan infeksi HIV. Rerata jumlah limfosit total pada anak gizi buruk dengan infeksi HIV lebih rendah dibandingkan tanpa infeksi HIV. Penelitian yang dilakukan oleh Bachou $\mathrm{dkk}^{1}$ tentang korelasi CD4 pada anak gizi buruk dengan dan tanpa HIV didapatkan jumlah limfosit total pada gizi buruk dengan HIV lebih rendah dibandingkan yang tanpa HIV, dan sekitar $46 \%$ anak gizi buruk dengan HIV pada usia 12-23 bulan, tetapi tidak terdapat perbedan yang bermakna berdasarkan kelompok umur.

Nilai cut-off dari jumlah limfosit total (TLC) pada penelitian kami adalah $3000 \mathrm{sel} / \mathrm{mm}^{3}$, dengan sensitifitas 86\% dan spesifisitas 55\%, PPV 50\%, dan NPV $88 \%$ dalam memprediksi jumlah limfosit total pada gizi buruk dengan infeksi HIV. Orbikorang $\mathrm{dkk}^{3}$ yang mencari cut-off dari jumlah limfosit total (TLC) untuk memprediksi jumlah CD4 pada pasien HIV dewasa didapatkan kategori TLC $1200 \mathrm{sel} /$ $\mathrm{mm}^{3}$ setara dengan CD $4<200 \mathrm{sel} / \mathrm{mm}^{3}$ (sensitivitas $72,2 \%$ dan spesifisitas $100 \%$ ), TLC $1500 \mathrm{sel} / \mathrm{mm}^{3}$ setara dengan CD4 200-499 sel/ $\mathrm{mm}^{3}$ (sensitivitas 
96,67\% dan spesifisitas 100\%), dan CD4 $2500 \mathrm{sel} /$ $\mathrm{mm}^{3}$ setara dengan TLC $1900 \mathrm{sel} / \mathrm{mm}^{3}$ (sensitivitas $98,45 \%$ dan spesifisitas $100 \%)$. Sedangkan menurut Gitura $\mathrm{dkk}^{9}$ untuk cut-off jumlah limfosit total (TLC) dalam prediksi jumlah CD4 mempunyai nilai yang lebih tinggi, yaitu $2100 \mathrm{sel} / \mathrm{mm}^{3}$ setara dengan CD $4<200 \mathrm{sel} / \mathrm{mm}^{3}$ (sensitifitas $83 \%$ dan spesifisitas 77\%, PPV 92\%, NPV 80\%). Penelitian lain oleh Gunarsa $\mathrm{dkk}^{5}$ tentang TLC yang digunakan sebagai parameter status nutrisi pada pasien gizi buruk dewasa yang dirawat di rumah sakit didapatkan TLC $\leq 1200 \mathrm{sel} / \mathrm{mm}^{3}$ berhubungan dengan status gizi kurang, sedangkan TLC $\leq 900 \mathrm{sel} / \mathrm{mm}^{3}$ berhubungan dengan status gizi buruk. Nilai cut-off TLC pada anak menurut Githinji $\mathrm{dkk}^{6}$ untuk kategori usia 1235 bulan adalah $6000 \mathrm{sel} / \mathrm{mm}^{3}$ dengan sensitivitas 65\% dan spesifisitas 62\%, PPV 61\%,NPV 65\%. Data tersebut mempunyai nilai ambang cut off yang lebih tinggi dari penelitian kami, tetapi dengan sensitifitas yang lebih rendah dan spesifisitas yang lebih tinggi. Nilai tersebut juga berbeda dengan yang direkomendasikan WHO untuk nilai cut-off TLC pada anak kategori usia 12-35 bulan, yaitu $3000 \mathrm{sel} /$ $\mathrm{mm}^{3}$ dengan sensitivitas $23 \%$ dan spesifisitas $98 \%$, PPV 93\%, NPV 58\%.

Hasil nilai cut-off jumlah limfosit total (TLC) pada penelitian kami sama dengan yang direkomendasikan WHO dengan nilai ambang $3000 \mathrm{sel} / \mathrm{mm}^{3}$, dengan sensitifitas $86 \%$ dan spesifisitas 55\%, PPV 50\% dan NPV $88 \%$, tetapi penelitian kami mempunyai nilai sensitifitas yang lebih tinggi dan spesifitas yang lebih rendah dari kriteria WHO. Adanya perbedaan hasil antara penelitian kami dan penelitian di Afrika serta rekomendasi WHO yang datanya diambil dari Amerika karena sampel berasal dari latar belakang negara yang berbeda kondisinya. Untuk penelitian dengan sampel yang diambil dari anak-anak di Afrika yang mempunyai latar belakang beban penyakit infeksi yang lebih berat dan harga normal $T$ sel sebelumnya yang berbeda dengan populasi di Indonesia maupun di Amerika. Masing- masing kondisi latar belakang dari setiap negara akan memengaruhi respons imun selular yang berbeda.

\section{Kesimpulan}

Anak gizi buruk dengan infeksi HIV mempunyai jumlah limfosit total yang lebih rendah dibandingkan gizi buruk tanpa infeksi HIV, terutama pada kelompok umur 12-23 bulan. Jumlah limfosit total dapat dijadikan skrining awal pada anak dengan tampilan klinis gizi buruk yang dicurigai menderita infeksi HIV, terutama pada sarana kesehatan terbatas sebelum dilakukan pemeriksaan serologi

\section{Daftar pustaka}

1. Bachou H, Tylleskar T, Downing R, Tumwine J. Severe malnutrition with and without HIV-1 infection in hospitalised children in Kampala Uganda: differences ini clinical features, haemalotological findings and CD4+ cell counts. Nutr J 2006;27:1-7.

2. Depkes RI. Pedoman tata laksana infeksi HIV dan pengobatan antiretroviral pada anak di Indonesia. 2008.

3. Obirikorang C, Quaye L, Acheampong I. Total lymphocyte count as a surrogate marker for CD 4 count in resource-limited settings. BMC Infect Dis 2012;12:15.

4. Franca T, Ishikawa L, Pezavento S, Minicucci C, Sartori A. Impact of malnutrition on immunity and infection. J Venom Anim Toxins incl Trop Dis 2009;15:374-90.

5. Gunarsa R, Simadibrata M, Syam F, Timan S, Setiati S, Rani A. Total Lymphocyte Count as a Nutritional Parameter in Hospitalized Patients. The Indonesian Journal of Gastroenterology, Hepatology, and Digestive Endoscopy 2011;12:89-94.

6. Ghitinji N, Obimbo E, Nderitu M, Wamalwa C, Ngacha D. Utility of total lymphocite count as a surrogate marker for CD4 counts in HIV-1 infected children in Kenya. BMC infect Dis 2011;11:1-8.

7. Hughes M, Amadi B, Mwiya. CD4 Counts Decline Despite Nutritional Recovery in HIV- Infected Zambian Children With Severe Malnutrition. Pediatrics 2009; 123:347-51.

8. Enwonwu C. Complex interactions between malnutrition, infection and immunity: relevance to HIV/AIDS infection. Nigerian J Paed 2006;1:1-6.

9. Gitura BM, Joshi MD, Lule GN, Anzala O. Total Lymphocyte count as a surrigate marker for CD4+ T cells count in initiating HAART at Kenyata National Hospital, Nairobi. East African Med J 2007;11:1-8.

10. Lavu E, Kutson N, Conniez C, Taue G. Total lymphocyte count as a nutritional parameter in hospitalized patients. PNG Med J 2004;47:31-8.

11. Wang Y, Li Y, Wang C. Total lymphocyte count 
as a surrogate marker to predict CD4 count in human immunodeficiency virus-infected children: a retrospective evaluation. Pediatr Infect Dis J 2012;31:61-3.

12. Johnson O, Benjamin D, Schimana W. Total lymphocyte count and world health organization pediatric clinical stage as marker to assess need to initiate antiretroviral therapy among human imunodeficiency virus-infected children in Moshi, Northern Tanzania. Pediatr Infect Dis J 2009;28:493-7. 